\title{
Implementasi Algoritma Weighted Sum Model Dalam Sistem Penjaminan Mutu Perguruan Tinggi
}

\author{
Sunardi $^{1}$, Abdul Fadlil ${ }^{1}$, Ryan Fitrian Pahlevi* ${ }^{2}$ \\ ${ }^{1}$ Program Studi Teknik Elektro, Universitas Ahmad Dahlan, Yogyakarta \\ ${ }^{2}$ Program Studi Magister Teknik Informatika, Universitas Ahmad Dahlan, Yogyakarta \\ e-mail: ${ }^{1}$ sunardi@mti.uad.ac.id, ${ }^{1}$ fadlil@mti.uad.ac.id, ${ }^{* 2}$ ryan1708048031@webmail.uad.ac.id
}

\begin{abstract}
Abstrak
Pemerintah Indonesia menyelenggarakan Sistem Penjaminan Mutu (SPM) Pendidikan Tinggi (PT) sebagai usaha dalam mewujudkan pendidikan yang bermutu. Muhammadiyah mengelola Perguruan Tinggi Muhammadiyah/'Aisyiyah (PTMA) dengan manajemen proses bisnis SPM sebagai bentuk pencapaian mutu Standar Nasional Pendidikan Tinggi (SN-DIKTI). Penjaminan mutu PT ditetapkan dalam Standar Mutu. Banyaknya kriteria dan keterkaitan dengan kegiatan penjaminan mutu menjadi persoalan yang diangkat pada penelitian ini. Penelitian difokuskan pada analisis metode pengambilan keputusan Weighted Sum Model (WSM) dalam Sistem Pendukung Keputusan (SPK) menggunakan algoritma Weighted Sum Model serta pengujian algoritma tersebut dalam implementasi di SPM PTMA. Algoritma WSM digunakan dan diuji pada basis data standar mutu dengan variabel pembanding antar metode yaitu relevansi, ciri, akurasi, presisi, reliabilitas, efektivitas, efisiensi, kelebihan, dan kekurangan. Hasil dan analisis penelitian adalah penggunaan algoritma WSM untuk menentukan prioritas dari 11 Proses Bisnis PT menjadi informasi bagi Pimpinan PTMA dalam memprediksi kegiatan strategis. Proses Analisis telah dilakukan dan diperoleh bahwa algoritma WSM digunakan dalam SPM PTMA dengan skor penilaian uji coba adalah sebesar $94 \%$.
\end{abstract}

Kata kunci - Sistem Penjaminan Mutu (SPM), Sistem Pendukung Keputusan (SPK), Perguruan Tinggi Muhammadiyah/'Aisyiyah (PTMA), Standar Mutu

\begin{abstract}
The Indonesia government implements a Quality Assurance System (QAS) of a Higher Education (HE) for realizing the quality education. Muhammadiyah manages several Muhammadiyah/'Aisyiyah College (MAC) with SPM Business Processes Management (BPM) as a form of achieving the quality of a National Higher Education Standards. A Quality Assurance (QA) of the HE is set in a Quality Standards (QS). The number of criteria and relationships with the QA activities become an issue which is appointed in this research. The research is focused on the analysis of the decision-making method Weighted Sum Model (WSM) in the Decision Support System (DSS). The research objective is the use of decision-making methods in the form of DSS using the WSM algorithm and testing the use of these algorithms in the implementation of the QAS in MAC. The WSM algorithm is used and tested on a quality standard database with comparison variables between methods, namely relevance, characteristics, accuracy, precision, reliability, effectiveness, efficiency, strength, and weaknesses.The results and analysis of the research is the use of the WSM algorithm to determine the priorities of the 11 HE Business Processes to inform PTMA Leaders in predicting strategic activities. The analysis process has been carried out and it is found that the WSM algorithm is used in the PTMA SPM with a test assessment score of 94\%.
\end{abstract}


Keywords - Quality Assurance System (QAS), Decision Support System (DSS), Muhammadiyah/'Aisyiyah College (MAC), Quality Standard.

\section{PENDAHULUAN}

$\mathrm{D}_{\mathrm{P}}^{\mathrm{D}}$ Dalam rangka mewujudkan pendidikan yang bermutu Indonesia menyelenggarakan Sistem Penjaminan Mutu (SPM) Perguruan Tinggi (PT), yaitu kegiatan sistemik dalam meningkatkan mutu secara terencana dan berkelanjutan. Kegiatan penjaminan mutu dibagi menjadi dua, yaitu Sistem Penjaminan Mutu Internal (SPMI) dan Sistem Penjaminan Mutu Eksternal (SPME). SPMI merupakan kegiatan pengelolaan/manajemen PT demi mencapai mutu atau kesesuaian yang dilaksanakan secara internal, sedangkan SPME dilakukan melalui kegiatan akreditasi yang menjadi gambaran tingkat mutu dalam penyelenggaraan PT.

Kegiatan SPMI yang memiliki kaitan erat dengan SPME dilakukan dalam siklus Perencanaan, Pelaksanaan, Evaluasi, Pengendalian, dan Peningkatan (PPEPP) yang merupakan kegiatan rutin dengan usaha pencapaian mutu. SPM yang dilakukan dengan rangkaian sistemik yang berkelanjutan menjadi persoalan yang cukup kompleks. Kompleksitas mutu yang perlu dicapai dan dikelola tersebut menjadikan permasalahan tersendiri dalam penyelenggaraan pendidikan, penelitian, dan pengabdian kepada masyarakat atau yang dikenal dengan tri dharma PT.

Perguruan Tinggi Muhammadiyah/'Aisyiyah (PTMA) sebagai Perguruan Tinggi Swasta (PTS) di bawah naungan Persyarikatan Muhammadiyah tidak terlepas dari persoalan pelaksanaan SPM [1]. PTMA menetapkan satu dharma tambahan, yaitu Al-Islam dan Kemuhammadiyahan sehingga menjadikan PTMA memiliki kegiatan penyelenggaraan tidak lagi tiga (tri dharma) melainkan menjadi empat (catur dharma). Kriteria mutu PTMA dapat ditunjukkan pada Tabel 1 [2] yang terdiri atas empat kriteria, yaitu stakeholder, statuta, perencanaan, dan penjaminan mutu dengan masing-masing memiliki standar mutu yang harus dijadikan perhatian.

Tabel 1. Kriteria dan Standar Mutu PTMA

\begin{tabular}{|l|l|}
\hline \multicolumn{1}{|c|}{ Kriteria } & \multicolumn{1}{c|}{ Standar Mutu } \\
\hline Stakeholder & Internal: mahasiswa, dosen, dan tenaga kependidikan \\
\cline { 2 - 3 } & $\begin{array}{l}\text { Eksternal: pemerintah, sivitas akademika, pegawai, orang } \\
\text { tua/wali mahasiswa, dewan penyantun/donatur, dan } \\
\text { masyarakat }\end{array}$ \\
\hline \multirow{5}{*}{ Statuta } & $\begin{array}{l}\text { Bisnis proses (aras Kewenangan): unsur organ, } \\
\text { pimpinan/rektorat, senat, Badan Pembina Harian (BPH), } \\
\text { Persyarikatan dalam hal ini Majelis Pendidikan Tinggi, } \\
\text { Penelitian, dan Pengembangan (Diktilitbang) Pimpinan } \\
\text { Pusat Muhammadiyah }\end{array}$ \\
\cline { 2 - 3 } Terencanaan & Tata pamong dan kelola \\
\hline Dokumen Strategis) & $\begin{array}{l}\text { Rencana Jangka Panjang atau Rencana Induk } \\
\text { Pengembangan (RIP) }\end{array}$ \\
\cline { 2 - 3 } & $\begin{array}{l}\text { Rencana Jangka Menengah dalam bentuk Rencana } \\
\text { Strategis (Renstra) }\end{array}$ \\
\cline { 2 - 3 } & $\begin{array}{l}\text { Standar mutu berupa Standar Nasional Pendidikan Tinggi } \\
\text { (SN-DIKTI) dan Standar Nasional Al Islam dan }\end{array}$ \\
& $\begin{array}{l}\text { Kemuhammadiyahan (SN-AIK) yang memuat Indikator } \\
\text { Kinerja Utama (IKU) dan Indikator Kinerja Tambahan } \\
\text { (IKT) }\end{array}$ \\
\hline
\end{tabular}

Sunardi, et., al [Implementasi Algoritma Weighted Sum Model Dalam Sistem Penjaminan Mutu Perguruan Tinggi] 


\begin{tabular}{|l|l|}
\hline \multirow{2}{*}{\begin{tabular}{|l|} 
Penjaminan Mutu \\
(SPMI, SPME, atau
\end{tabular}} & $\begin{array}{l}\text { Rencana Jangka Pendek dalam bentuk Rencana } \\
\text { Operasional (Renop) }\end{array}$ \\
\cline { 2 - 2 } Manajemen Mutu) & Rencana Anggaran Pendapatan dan Belanja (RAPB) \\
\cline { 2 - 2 } & Pencencanaan, Pelaksanaan, Evaluasi, Pengendalian, dan \\
\cline { 2 - 2 } & Evaluasi, Penetapan, dan Pemantauan (EPP) \\
\cline { 2 - 2 } & Plan, Do, Check, and Act (PDCA) \\
\hline
\end{tabular}

Pengelolaan PTMA digambarkan dalam 11 manajemen proses bisnis, yaitu [2]: 1) pendidikan, 2) pengembangan suasana akademik, dan otonomi keilmuan, 3) administrasi umum dan keuangan, 4) perencanaan dan penjaminan mutu, serta sistem informasi, 4) organisasi dan kerjasama, 5) kemahasiswaan, 6) penelitian, 7) pengabdian kepada masyarakat, 8) Al Islam dan Kemuhammadiyahan, 9) sumber daya manusia, 10) Sarana, dan 11) Prasarana. Banyaknya kriteria dan keterkaitan dengan kegiatan penjaminan mutu serta penetapan keputusan tersebut menjadi persoalan yang diangkat dalam penelitian ini. Metode pengambilan keputusan diyakini mampu diaplikasikan dalam penetapan keputusan pimpinan PTMA untuk SPM. Oleh karena itu, penelitian ini melakukan analisis serta penggunaan metode pengambilan keputusan Weighted Sum Model (WSM) dalam Sistem Pendukung Keputusan (SPK) dengan tujuan menentukan prioritas proses bisnis yang dijadikan informasi bagi Pimpinan PTMA dalam memprediksi kegiatan strategis.

Penelitian ini menggunakan algoritma WSM sebagai metode pengambilan keputusan untuk SPM PTMA. Algoritma ini dipilih karena merupakan metode pendukung keputusan yang sangat umum digunakan, sangat sederhana, dan mudah dipahami penerapannya dibanding metode lain dikarenakan dalam konsep metode ini hanya melakukan perkalian di antara Bobot Kriteria dan Nilai Alternatif [3].

Penelitian ini dilakukan dengan kajian penelitian terdahulu yang memiliki relevansi dalam pembahasannya, salah satunya adalah sistem informasi data warehouse untuk mendukung SPMI [4]. Kriteria-kriteria akreditasi PT digunakan sebagai item-item pengumpulan data warehouse. Penelitian tersebut menghasilkan data informasi antara lain pembuatan data warehouse, kriteria-kriteria akreditasi PT, kebutuhan sistem informasi dalam bentuk aplikasi data warehouse SPMI, dan data kebutuhan untuk perancangan. Penelitian lain [4] terkait pengambilan keputusan, yaitu menganalisis dan merancang sistem pengambilan keputusan dalam seleksi asisten laboratorium yang diharapkan membantu dalam pengembangan sistem pengambilan keputusan menghasilkan rancangan sistem yang membantu pengolahan data dalam proses pengambilan keputusan seleksi asisten di Jurusan Teknik Informatika UPN "Veteran" Yogyakarta.

Penelitian terkait penggunaan SPK berbasis data [5] dihasilkan informasi dan pengetahuan tentang dinamika lowongan kerja dan keterampilan, konsentrasi pada unti wilayah, dan kegiatan ekonomi. Penelitian tersebut menghasilkan penyajian hasil eksperimen dalam konteks pasar tenaga kerja. Penelitian tentang SPK dilakukan untuk seleksi peserta didik baru menggunakan metode AHP dan Simple Additive Weighting (SAW). Pembobotan kriteria menggunakan metode AHP, sementara metode SAW digunakan untuk menentukan perankingan alternatif. Hasil dari penelitian tersebut adalah AHP dan SAW dapat diterapkan pada SPK pada seleksi penerimaan peserta didik SMA. Penelitian [6] melakukan pengembangan SPK dengan metode AHP untuk penilaian kompetensi soft skill karyawan. Hasil penelitian membuktikan bahwa metode AHP dapat digunakan. Penelitian lain terkait penilaian maupun membandingkan metode adalah membandingkan metode certainty factor dengan metode probabilitas Bayes pada ahli penyakit THT dihasilkan bahwa metode certainty factor memiliki akurasi sebesar $100 \%$, sementara metode probabilitas Bayes hanya sebesar 80\% [9] 
Penelitian terkait WSM dilakukan dengan mengimplementasikan metode WP dan metode WSM kemudian dibandingkan dengan hasil perangkingan manual oleh perusahaan " $\mathrm{X}$ " [7]. Hasil perbandingan dari penelitian ini ditinjau dari segi akurasi dan error. Berdasar kecepatan compile, metode WSM memerlukan sedikit waktu dibandingkan dengan metode WP. Penelitian lain terkait WSM [8] (Mesran, Suginam, Nasution, \& Siahaan, 2017) (Mesran, Suginam, Nasution, \& Siahaan, 2017) [8] (Mesran, Suginam, Nasution, \& Siahaan, 2017) [8] [8] untuk Penentuan Peserta Jaminan Kesehatan Masyarakat (Mesran) serta penerapan salah satu Multi-Criteria Decision Making (MCDM) mampu untuk mengatasi kendala yang dihadapi pemerintah [8].

Penggunaan algoritma WSM diharapkan mampu menjadi alat bantu dalam kegiatan pengambilan keputusan dari banyaknya kriteria dan keterkaitan dalam kegiatan penjaminan mutu. Tujuan penelitian ini adalah penggunaan metode pengambilan keputusan dalam bentuk SPK menggunakan algoritma WSM serta pengujian algoritma tersebut dalam implementasi di SPM PTMA.

\section{METODE PENELITIAN}

\subsection{Desain Sistem}

Sistem dibangun bersamaan dengan basis data serta alat bantu perhitungan dalam pengambilan keputusan. Desain sistem dibangun berdasarkan peta pemikiran SPM PTMA seperti ditunjukkan pada Gambar 1. Kebutuhan penyelenggaraan PTMA dengan urutan kebutuhan peraturan tertinggi PTMA, yaitu Statuta, dilanjut dengan perencanaan rencana (jangka panjang, menengah, dan pendek), kemudian diperinci dalam standar mutu, dan beberapa kebutuhan sumber daya, yaitu keuangan dan dokumen mutu.

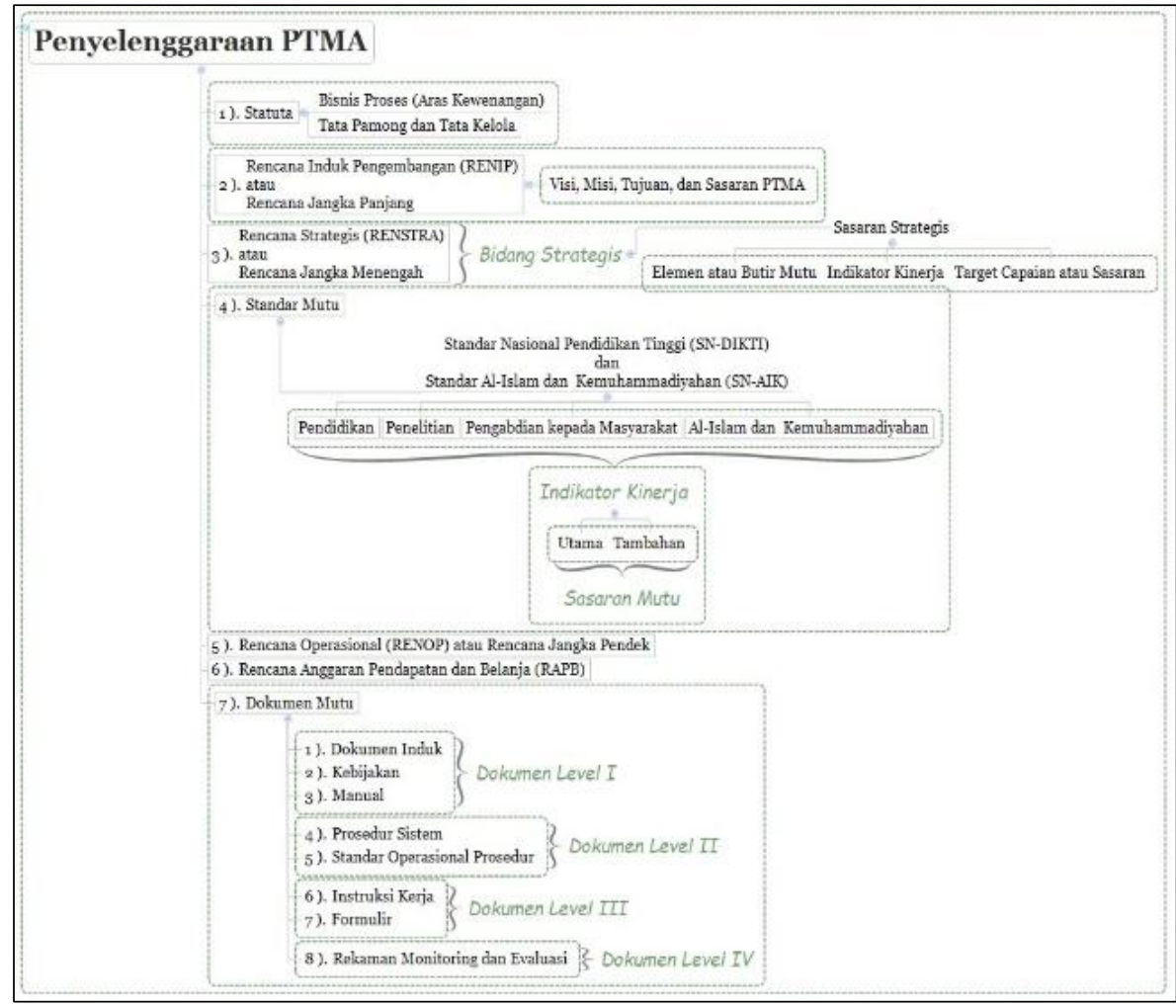

Gambar 1. Peta Pemikiran Penyelenggaraan PTMA Dalam SPM 
Peta pemikiran pencapaian visi, misi, tujuan, dan sasaran (VMTS) dalam proses pengelolaan/penyelenggaraan PT ditunjukkan pada Gambar 2. Peta pemikiran dalam proses pencapaian VMTS berdasarkan regulasi pemerintah yang diturunkan dalam statuta PT dan penetapan standar mutu dalam perencanaan yang kemudian terdapat tata pamong dan kelola PTMA dan kebutuhan sumber daya berupa keuangan, sarana, dan prasarana.

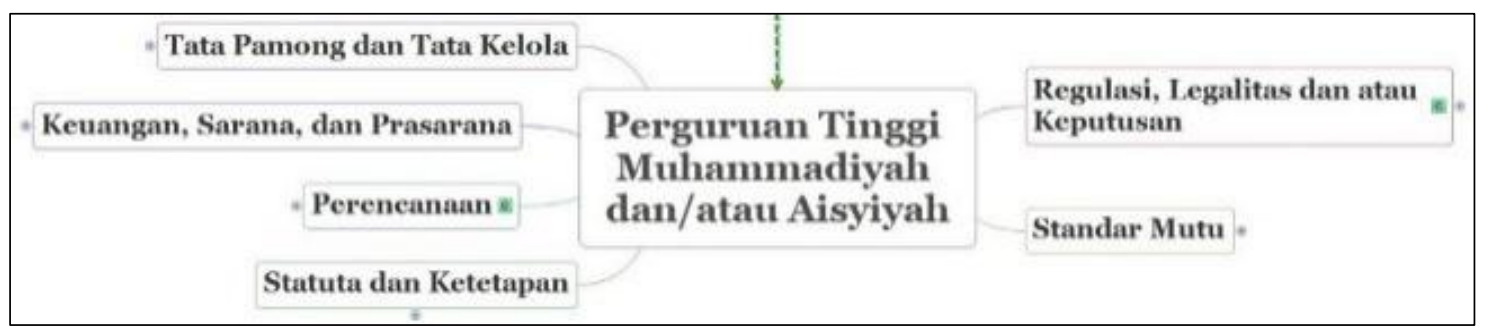

Gambar 2. Peta Pemikiran Pencapaian Visi, Misi, Tujuan, dan Sasaran

Kriteria didefinisikan berdasarkan Parameter, Kriteria, dan/atau Variabel yang dibutuhkan untuk mendapatkan ranking akhir. Rangking akhir yang diperoleh adalah urutan rangking dari Proses Bisnis yang menjadi acuan pimpinan PTMA dalam membuat keputusan.

SPK dimulai dengan Mendefinisikan Kriteria, Proses Pengambilan Keputusan, dan selanjutnya diperoleh Ranking dan Hasil Akhir (Gambar 3). Konsep sistem ini dibuatkan sistem Manajemen Penjaminan Mutu PTMA menggunakan aplikasi Microsoft Excel dengan membangun Basis Data Standar Mutu (sebagai penghubung Penyelenggaraan PTMA serta kriteria Pencapaian VMTS) dan diintegrasikan dengan Metode Pengambilan Keputusan. Parameter, Kriteria, dan/atau Variabel yang muncul dari basis data dapat dilihat pada Tabel 2.

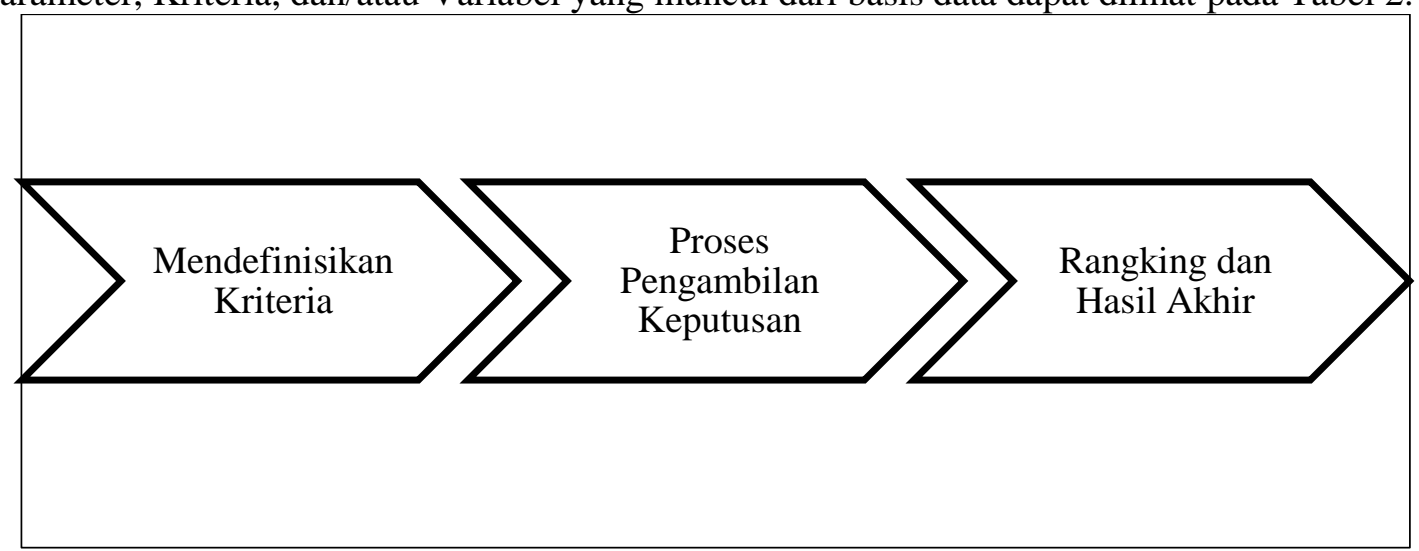

Gambar 3. Konsep Sistem Pendukung Keputusan

Parameter, Kriteria, dan/atau Variabel tersebut didefinisikan kedalam Metode Pengambilan Keputusan WSM dan diterapkan di SPM. Analisis dilakukan dengan mendapatkan nilai dari kriteria yang ditetapkan (Tabel 2) berdasarkan siklus PPEPP dalam pelaksanaan penjaminan mutu dengan nilai bobot berdasarkan bobot pelaksanaan siklus. Pengisian kriteria dilakukan secara subjektif dengan pertimbangan penelitian ini adalah uji coba metode. Data yang dikumpulkan dapat berbentuk data kualitatif dan data kuantitatif yang dalam penelitian ini berarti merupakan gabungan atau kombinasi dari keduanya.

Kriteria yang ditentukan merupakan siklus dari kegiatan SPMI [9] antara lain: 1) penetapan Standar PT; 2) pelaksanaan Standar PT; 3) evaluasi pelaksanaan Standar PT; 4) pengendalian pelaksanaan Standar PT; dan 5) peningkatan Standar Pendidikan Tinggi. Kegiatan-kegiatan tersebut kemudian ditetapkan menjadi kriteria (C1 hingga C5). 
GAP [10] adalah nilai kesenjangan (-5 hingga 5 [11]) antar kinerja suatu variabel atau dalam hal ini adalah kriteria. Analisis GAP [3] dari perencanaan (C1) ditetapkan bernilai 3 yang berarti bahwa memiliki kelebihan pada tingkat 3. Analisis GAP dari pelaksanaan (C2) ditetapkan bernilai 5 yang berarti bahwa memiliki kelebihan pada tingkat 5. Analisis GAP dari Evaluasi (C3) ditetapkan bernilai 4 yang berarti bahwa memiliki kelebihan pada tingkat 4. Analisis GAP dari pengendalian (C4) ditetapkan bernilai 2 yang berarti bahwa memiliki kelebihan pada tingkat 2. Kemudian analisis GAP dari perencanaan (C5) ditetapkan bernilai 1 yang berarti bahwa memiliki kelebihan pada tingkat 1. [12]

Nilai bobot adalah masing-masing bobot dari 5 kriteria yang ditetapkan dengan nilai bobot keseluruhan bernilai 1 (100\%). Perencanaan merupakan kegiatan awal dari suatu penetapan standar PT, ditetapkan memiliki bobot 0,20 (20\%). Pelaksanaan merupakan kegiatan implementasi standar yang telah ditetapkan, menjadikan kegiatan pelaksanaan adalah kegiatan yang memiliki porsi bobot yang besar. Hal ini menjadi dasar penetapan bobot dari pelaksanaan adalah $0,40(40 \%)$. Kegiatan pelaksanaan yang telah berjalan kemudian dilakukan kegiatan evaluasi serta monitoring pencapaian dari perencanaan dan pelaksanaan standar PT, bobot evaluasi bernilai $0,25(25 \%)$. Pengendalian merupakan kegiatan lanjutan dari evaluasi yang telah dilakukan, dimaksudkan untuk mengendalikan standar dari temuan baik temuan positif maupun negatif, dan kegiatan pengendalian diberikan nilai bobot sebesar 0,10 (10\%). Peningkatan merupakan penetapan dari tindak lanjut siklus-siklus sebelumnya agar kemudian dilakukan tindakan perencanaan standar PT kembali, peningkatan diberi nilai bobot 0,05 (5\%).

Parameter, kriteria, dan/atau variabel standar mutu ditetapkan dari semua kriteria adalah benefit [3] yang berarti bahwa berguna atau bermanfaat dan memang diperlukan dalam siklus SPM baik itu SPMI ataupun SPME.

Tabel 2. Parameter, Kriteria, dan/atau Variabel Standar Mutu

\begin{tabular}{|c|l|c|c|c|}
\hline \multicolumn{2}{|c|}{ Nama Kriteria } & Analisis GAP & Nilai Bobot & Kriteria \\
\hline C1 & Perencanaan & 3 & 0,20 & Benefit \\
\hline C2 & Pelaksanaan & 5 & 0,40 & Benefit \\
\hline C3 & Evaluasi & 4 & 0,25 & Benefit \\
\hline C4 & Pengendalian & 2 & 0,10 & Benefit \\
\hline C5 & Peningkatan & 1 & 0,05 & Benefit \\
\hline
\end{tabular}

\subsection{Pengujian}

Data yang terkumpul diperoleh dengan mengisi nilai pencapaian standar dalam Basis Data Standar Mutu PTMA berupa file Excel yang dianalisis menggunakan algoritme WSM dengan tujuan mendapatkan hasil yang diharapkan sesuai hipotesis penelitian yaitu WSM baik digunakan sebagai alat bantu dalam kegiatan pengambilan keputusan dari banyaknya kriteria dan keterkaitan dalam kegiatan penjaminan mutu.

Metode dilaksanakan dengan tahapan proses pengambilan keputusan dan penilaian algoritma WSM, yaitu [14]:

1. Relevansi: algoritma dapat dihubungkan antara kriteria dengan metode pendukung keputusan yang digunakan sehingga bahwa kriteria yang ada mampu dimasukkan kedalam formula

2. Ciri metode: merupakan karakteristik yang membedakan antara algoritma satu dengan algoritma yang lain

3. Akurasi: kemampuan algoritma ketika digunakan mampu memberikan nilai yang tepat

4. Presisi: kemampuan algoritma untuk memberikan nilai dengan ketelitian yang tinggi

5. Reliabel: kemampuan algoritma dalam memberikan nilai yang konstan/tepat bila digunakan berkali-kali 
6. Efektivitas: algoritma mampu memberikan hasil sesuai dengan tujuan digunakannya algoritma tersebut

7. Efisiensi: algoritma mampu memberikan hasil yang sesuai dengan langkah yang singkat

8. Kelebihan: kemampuan algoritma yang menjadi nilai lebih sebagai pertimbangan untuk digunakan

9. Kekurangan: nilai algoritma yang menjadi pertimbangan untuk ditingkatkan atau dihindari

Variabel pembanding antar metode digunakan sebagai kriteria penilaian untuk metode pengambilan keputusan yang diuji coba dengan cara memberi skor penilaian dari 0 (tidak dinilai) yang merupakan nilai terendah dan bermakna belum dianjurkan hingga 4 (sangat baik) seperti ditunjukkan pada Tabel 3 .

Tabel 3. Skala Skor Penilaian

Parameter Pembanding

\begin{tabular}{|c|l|}
\hline Skala & \multicolumn{1}{|c|}{ Kualitas } \\
\hline 0 & Tidak dinilai \\
\hline 1 & Sangat kurang \\
\hline 2 & Kurang \\
\hline 3 & Baik \\
\hline 4 & Sangat Baik \\
\hline
\end{tabular}

WSM merupakan algoritma pendukung keputusan yang sangat umum digunakan dalam membantu kegiatan pengambilan keputusan. WSM merupakan salah satu algoritma yang sangat sederhana dan mudah dipahami penerapannya karena hanya melakukan perkalian di antara Bobot Kriteria dan Nilai Alternatif, dengan langkah sebagai berikut [3]:

1. Mengidentifikasi Kriteria dan Alternatif yang digunakan dalam penyelesaian masalah

2. Menghitung WSM-Score:

$$
A_{i}^{W S M-S c o r e}=\sum_{j=1}^{n} w_{j} x_{i j}
$$

dimana:

$n$ adalah jumlah kriteria

$w_{j}$ adalah bobot dari setiap kriteria

$x_{i j}$ adalah nilai matrik $x$

3. Melakukan perankingan

\section{HASIL DAN PEMBAHASAN}

\subsection{Penggunaan Sistem}

Hasil penelitian disajikan pada Gambar 4 diperoleh dengan menetapkan indikator kinerja serta target capaian yang dikelompokkan berdasarkan 11 proses bisnis PTMA dan kemudian melakukan penilaian algoritma WSM dengan 9 sisi yaitu mewakili: 1) relevansi, 2) ciri, 3) akurasi, 4) presisi, 5) reliabilitas, 6) efektivitas, 7) efisiensi, 8) kelebihan, dan 9) kekurangan. Pemberian skor pada standar (kriteria) menggunakan angka 0 hingga 4 sesuai Tabel 3. Penyajian Gambar 4 menggunakan grafik radar 9 sisi dan skor yang membentuk 4 layer radar. Basis data diintegrasikan dengan formula matematis SPK (WSM) pada Persamaan (1) untuk menentukan prioritas proses bisnis sebagai informasi bagi pimpinan PTMA dalam memprediksi kegiatan strategis. 


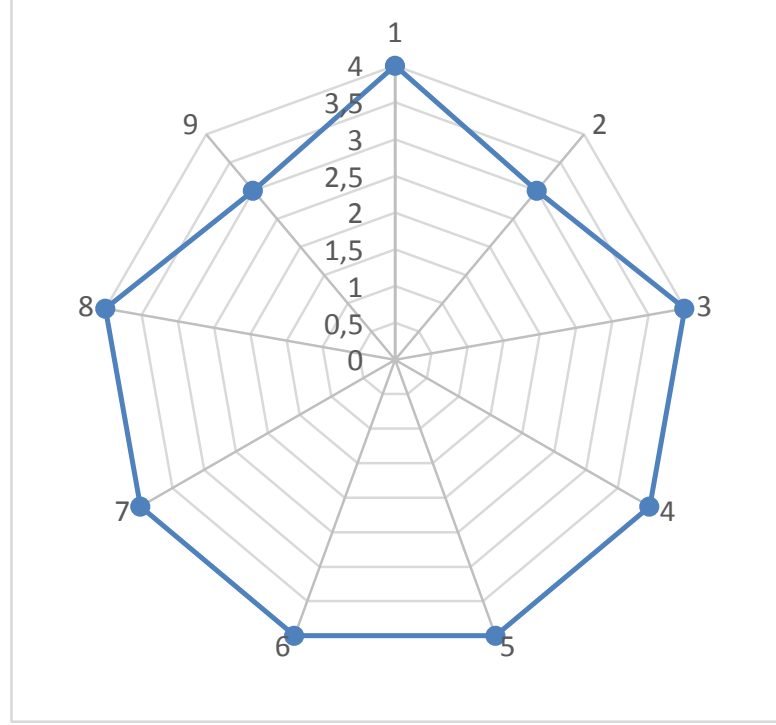

Gambar 4. Hasil Pengujian WSM

\subsubsection{Hasil Penggunaan Sistem}

Proses bisnis yang merupakan pengelompokan dari standar-standar yang ditetapkan PT diharapkan mampu mengelompokkan begitu banyaknya standar pada PT agar PT mampu mengidentifikasi kegiatan penyelenggaraan yang didasarkan atas standar yang dalam hal ini adalah standar mutu. Standar Mutu yang diperinci dalam Butir Mutu untuk selanjutnya ditetapkan Indikator Kinerja serta Target Capaian seperti pada Gambar 5. Standar mutu ditetapkan PT yang kemudian dipecah menjadi butir-butir mutu yang masing-masing memiliki indikator kinerja. Indikator kinerja merupakan parameter mutu kegiatan yang dilakukan di PT dan dapat ditentukan lima macam target capaian dengan skor $0,1,2,3$, dan 4 .

Pengelolaan atau manajemen PT dinilai kinerja pencapaiannya dengan pengisian kriteria PPEPP yang dikelompokkan berdasarkan 11 proses bisnis menjadi data pivot. Hasil dari pengisian kinerja pencapaian secara subjektif disajikan pada Tabel 4 yang diperoleh dengan cara memasukkan skor (0 hingga 4) pada masing-masing indikator kinerja dengan target capaian yang direncanakan. Target capaian tersebut merupakan hasil penilaian internal dari PT. Skor yang telah ditetapkan pada Tabel 4 selanjutnya digunakan untuk menghitung bobot kriteria untuk perhitungan urutan ranking proses bisnis menggunakan algoritma WSM. Perhitungan ranking menggunakan metode pengambilan keputusan dilakukan dengan memasukkan nilai pada Tabel 2 dan Tabel 4 ke Persamaan (1). 


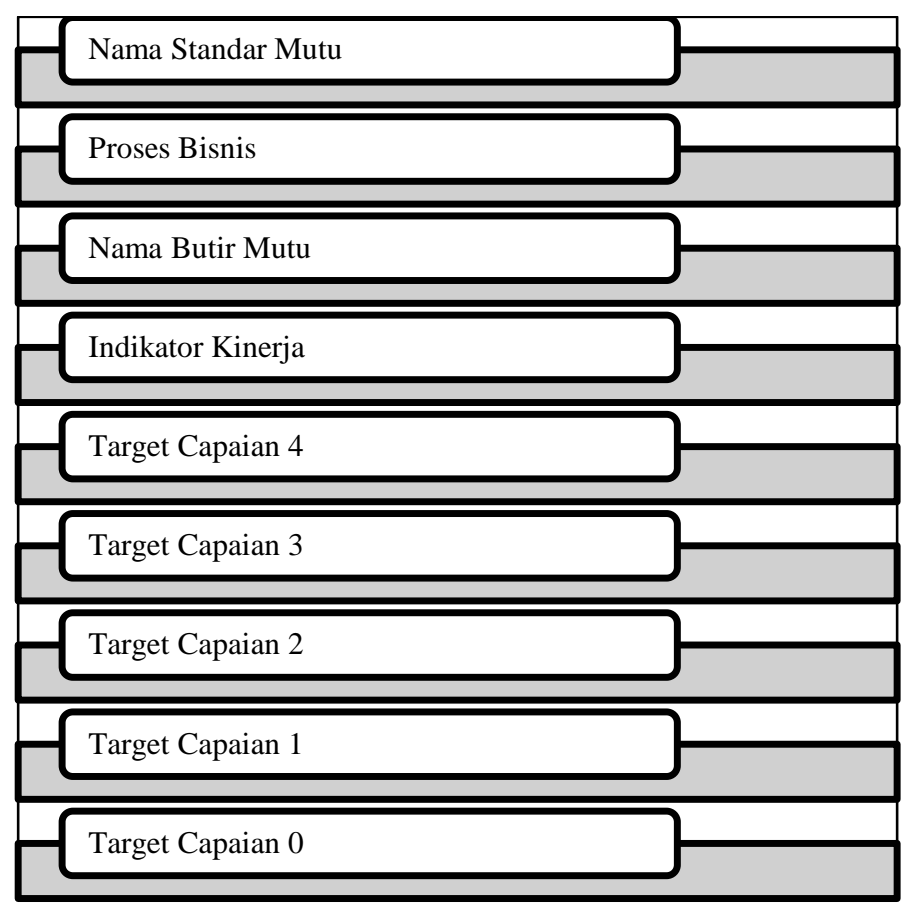

Gambar 5. Indikator Kinerja pada Standar Mutu Dapat Dikelompokkan Dalam Proses Bisnis

Tabel 4. Pencapaian Indikator Kinerja (Subjektif)

\begin{tabular}{|c|c|c|c|c|c|c|}
\hline No. & Proses Bisnis & 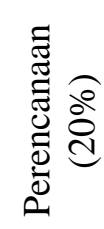 & 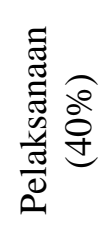 & 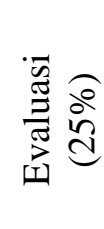 & 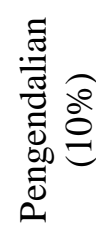 & 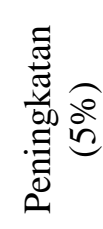 \\
\hline 1. & $\begin{array}{l}\text { Pendidikan, Pengembangan Suasana } \\
\text { Akademik dan Otonomi Keilmuan }\end{array}$ & 0,990 & 0,733 & 0,631 & 0,724 & 0,879 \\
\hline 2. & Administrasi Umum dan Keuangan & 0,901 & 0,605 & 0,485 & 0,575 & 0,625 \\
\hline 3. & $\begin{array}{l}\text { Perencanaan dan Penjaminan Mutu, serta } \\
\text { Sistem Informasi }\end{array}$ & 0,834 & 0,440 & 0,281 & 0,409 & 0,643 \\
\hline 4. & Organisasi dan Kerjasama & 0,914 & 0,575 & 0,430 & 0,571 & 0,578 \\
\hline 5. & Kemahasiswaan & 0,847 & 0,799 & 0,764 & 0,764 & 0,579 \\
\hline 6. & Penelitian & 0,998 & 0,170 & 0,136 & 0,080 & 0,832 \\
\hline 7. & Pengabdian kepada Masyarakat & 0,998 & 0,251 & 0,293 & 0,240 & 0,864 \\
\hline 8. & Al-Islam dan Kemuhammadiyahan & 1,000 & 0,418 & 0,336 & 0,364 & 0,369 \\
\hline 9. & Sumber Daya Manusia & 0,861 & 0,476 & 0,397 & 0,488 & 0,754 \\
\hline 10. & Sarana & 0,898 & 0,442 & 0,361 & 0,414 & 0,879 \\
\hline 11. & Prasarana & 0,995 & 0,319 & 0,309 & 0,351 & 0,981 \\
\hline
\end{tabular}

\subsubsection{Hasil Analisis Data}

Hasil dari analisis data yang telah dilakukan menjadi bahan untuk kegiatan uji coba dengan nilai skor sembilan variabel pembanding antar metode. Hasil Penelitian dapat diperoleh dengan memasukkan nilai dari Tabel 5 diperoleh nilai WSM sebesar $94 \%$. 


\subsection{Hasil Pengujian}

Skor penilaian yang didapatkan adalah pencapaian algoritma WSM yang diperoleh berdasarkan perhitungan dari penilaian sembilan variabel. Penilaian algoritma WSM ditunjukkan pada Tabel 5 yang masing-masing diuji dan diberikan skor (0 hingga 4). Hasil pada Tabel 5 dengan menghitung nilai rata-rata skor dikali $100 \%$ dan diperoleh nilai algoritma WSM adalah $94 \%$.

Tabel 5. Pengujian

\begin{tabular}{|c|c|c|c|}
\hline No. & Pengujian & Pembahasan & Skor \\
\hline 1 & Relevansi & $\begin{array}{l}\text { Parameter, Kriteria, dan/atau } \\
\text { Variabel mampu didefinisikan }\end{array}$ & 4 \\
\hline 2 & Ciri Metode & $\begin{array}{l}\text { Alternatif yang digunakan } \\
\text { dapat berupa nilai } 0 \text { hingga } 1\end{array}$ & 4 \\
\hline 3 & Akurasi & $\begin{array}{l}\text { Perhitungan nilai alternatif } \\
\text { dapat dilakukan secara } \\
\text { persentase, mengurangi risiko } \\
\text { perhitungan yang panjang }\end{array}$ & 4 \\
\hline 4 & Presisi & $\begin{array}{l}\text { Bila formula diinputkan secara } \\
\text { benar, hasil diperoleh } \\
\text { kepresisian tinggi dengan } \\
\text { toleransi yang kecil }\end{array}$ & 4 \\
\hline 5 & Reliabel & $\begin{array}{l}\text { Metode dapat digunakan } \\
\text { secara berulang-ulang dengan } \\
\text { nilai alternatif kriteria yang } \\
\text { diubah-ubah }\end{array}$ & 4 \\
\hline 6 & Efektivitas & $\begin{array}{l}\text { Metode cukup efektif } \\
\text { memberikan informasi terkait } \\
\text { urutan rangking proses bisnis }\end{array}$ & 4 \\
\hline 7 & Efisiensi & 3 langkah proses perhitungan & 4 \\
\hline 8 & Kelebihan & $\begin{array}{l}\text { Operasi perhitungan relatif } \\
\text { sederhana dengan efisiensi } \\
\text { tinggi }\end{array}$ & 4 \\
\hline 9 & Kekurangan & $\begin{array}{l}\text { Detail kriteria yang } \\
\text { didefinisikan minim }\end{array}$ & 3 \\
\hline
\end{tabular}

Relevansi algoritma dengan parameter, kriteria, dan/atau variabel yaitu Standar Mutu, Butir Mutu, Indikator Kinerja beserta dengan target capaiannya dinilai bahwa mampu untuk didefinisikan pada algoritma WSM (Persamaan 1) dan dapat digunakan pada SPM PTMA. Algoritma WSM memiliki ciri yang bisa berbeda dengan algoritma lain, ciri tersebut adalah pada algoritma ini terdapat perhitungan nilai alternatif berupa nilai 0 dan 1 . WSM mampu memberikan nilai yang tepat, sebab dalam algoritma ini nilai alternatif dapat dilakukan secara persentase, hal ini mengurangi risiko perhitungan yang panjang. Kepresisian algoritma WSM terlihat bila formula diinputkan secara benar, hasil diperoleh kepresisian tinggi dengan toleransi yang kecil. Reliabel algoritma dimaksudkan bahwa algoritma WSM dapat digunakan secara berulang-ulang walaupun nilai alternatif kinerja yang diubah-ubah atau ketika data input yang baru di waktu yang berbeda diinputkan. WSM dinilai cukup efektif dan efisien yaitu mampu memberikan informasi terkait urutan ranking proses bisnis SPM PTMA dan dilakukan dengan tiga langkah perhitungan (identifikasi kriteria dan alternatif, perhitungan nilai WSM, dan perankingan). Kelebihan algoritma WSM dalam penggunaannya di SPM PTMA adalah operasi 
perhitungan relatif sederhana dengan efisiensi tinggi namun terdapat kekurangan bahwa detail kriteria yang didefinisikan cukup minim sehingga tidak mampu mendefinisikan sub kriteria.

\section{KESIMPULAN}

Metode Pengambilan Keputusan digunakan untuk menentukan prioritas dari 11 Proses Bisnis PT menjadi informasi bagi Pimpinan PTMA dalam memprediksi kegiatan strategis. Proses Analisis telah dilakukan dan diperoleh bahwa algoritma WSM digunakan dalam SPM PTMA dengan skor penilaian uji coba adalah sebesar $94 \%$.

\section{SARAN}

Saran yang dapat diberikan terkait penelitian ini adalah hasil dari penelitian ini diharapkan dilanjut dalam mengembangkan sistem yang lebih user friendly sehingga dapat digunakan sebagai sistem untuk merencanakan, memantau kinerja, mengevaluasi pencapaian, mengendalikan, dan mengembangkan kegiatan penyelenggaraan pencapaian mutu Perguruan Tinggi khususnya PTMA.

\section{DAFTAR PUSTAKA}

[1]. PP Muhammadiyah. 2016, Pedoman Tentang Perguruan Tinggi Muhammadiyah, Majelis Diktilitbang PP Muhammadiyah, Yogyakarta.

[2]. Nurmandi, A., Muttaqin, A., Akbar, B., Fernandez, D., Arofiati, F., Mufdlilah, ... Suranto. 2019, Pedoman SPMI PTMA - Sistem Penjaminan Mutu Internal Perguruan Tinggi Muhammadiyah 'Aisyiyah (SPMI 4.0), Majelis Diktilitbang PP Muhammadiyah, Yogyakarta.

[3]. Fajarwati, I., Fitriasari, N. S., \& Siregar, H. 2018, Perbandingan Metode Weighted Product (WP), Weighted Sum Model (WSM) dan Multi Attribute Utility Theory (MAUT) Dalam Sistem Pendukung Keputusan Penerimaan Tenaga Kerja, Jurnal Teori dan Aplikasi Ilmu Komputer, 1(1), 25-32.

[4]. Nofriansyah, D., \& Defit, S. 2017, Multi Criteria Decision Making (MCDM): pada Sistem Pendukung Keputusan, Deepublish, Yogyakarta.

[5]. Astari, S. R., Umar, R., \& Sunardi. 2018, Analisis dan Perancangan Sistem Pengambilan Keputusan Dalam Seleksi Asisten Laboratorium, Seminar Nasional Informatika 2018 (SemnasIF 2018), 2018(November), 13-20. Yogyakarta.

[6]. Brandas, C., Panzaru, C., \& Filip, F. G. 2016, Data Driven Decision Support Systems: An Application Case in Labour Market Analysis, Romanian Journal of Information Science and Technology, 19(1-2), 65-77.

[7]. Umar, R., Fadlil, A., \& Yuminah, Y. 2018, Sistem Pendukung Keputusan dengan Metode AHP untuk Penilaian Kompetensi Soft Skill Karyawan, Khazanah Informatika: Jurnal Ilmu Komputer dan Informatika, 4(1), 27. https://doi.org/10.23917/khif.v4i1.5978 
[8]. Mesran, M., Suginam, S., Nasution, S. D., \& Siahaan, A. P. U. 2017, Penerapan Weighted Sum Model (WSM) Dalam Penentuan Peserta Jaminan Kesehatan Masyarakat, Jurasik (Jurnal Riset Sistem Informasi dan Teknik Informatika), 2(1), 40. https://doi.org/10.30645/jurasik.v2i1.17

[9]. Menristekdikti. 2016, Permenristekdikti No 62 Tahun 2016 Tentang Sistem Penjaminan Mutu Pendidikan Tinggi.

[10]. Pratiwi, H. 2016, Buku Ajar Sistem Pendukung Keputusan, Deepublish, Yogyakarta.

[11]. Latif, L. A., Jamil, M., \& Abbas, S. H. 2018, Sistem Pendukung Keputusan Teori dan Implementasi, Deepublish, Yogyakarta.

[12]. Sari, F. 2020, Metode Dalam Pengambilan Keputusan (ed. II), Deepublish, Yogyakarta. 